\title{
The Ontario University System as Wealth-Creator: Who Benefits? Who Pays?
}

\author{
OZAY MEHMET*
}

\begin{abstract}
This study is based on the assumption that university, inter alia, functions as a wealthcreator; as a result, it can effectively influence the distribution of income among groups and individuals. Since the Ontario university system is heavily financed out of general tax revenues, and supplied as a leading form of "public good," considerations of equity require that the system should serve both the principle of equality of opportunity as well as that of equality of results for all groups. An empirical evaluation of the system, based on the class of 1974 full-time male undergraduates, found that the present university education in the province is significantly regressive, tending to create wealth for, and shift income distribution in favour of, the higher income groups.
\end{abstract}

\section{RÉSUMÉ}

"Le système universitaire de l'Ontario, comme porte ouverte à de meilleurs revenus: qui en bénéficie? qui paye?"

Le présent travail prémume au depart que l'université a entre autres rôles, celui d'assurer à ses étudiants de bons revenus et comme conséquence peut influencer la distribution de revenus entre les groupes et les individus. Comme les universités de l'Ontario reçoivent leurs fonds en grande partie des revenus publics, une répartition équitable supposerait que tout groupe a droit aux mêmes chances et occasions de succès. Cependant une enquête basée sur l'année scolaire 1974 parmi un groupe d'étudiants à temps pleins, tous mâles, révèla que l'éducation universitaire en Ontario a des effets rétrogrades, et a tendance à stimuler l'acquisition de gros revenus surtout chez les etudiants venant de classes favorisées. 


\section{Ozay Mehmet}

Equity and efficiency implications of the supply of public goods have become major issues of contemporary Canadian policy. Fundamental questions are being raised by taxpayers as well as by skeptical observers about the "liberal economic philosophy" concerning the size and efficiency of government, and about the impact of expenditure policies on the distribution of income among Canadians. There is a general mood that government has become too big, that the supply of public goods, financed out of tax revenues, is no longer increasing the social real income, (i.e., it is becoming socially counter-productive). This general anti-government mood finds expression variously in calls for cuts in the size of bureaucracy, for balanced budgets, for dismantling and limiting regulatory powers, and for submitting public expenditure programs to rigorous tests of cost-effectiveness or social benefit-cost appraisals.

Nor is this anti-government mood a mere casual or ill-informed "fad" likely to go away without any major consequence. In fact, there is supporting evidence that it reflects a deep and far-reaching problem with the delivery system of public goods in Canada, and, more precisely, with the impact on income distribution of that delivery system*. In aggregate terms, for example, recent data from Statistics Canada show that there has been increased inequality in the size distribution of personal income, notwithstanding a tremendous expansion of transfer and welfare programs during the past decades. The ratio of the income share of the richest quintile to that of the lowest quintile for all Canadian families and unattached individuals rose from 9.4 in 1965 to 10.6 in 1974 (11, Table 53) - an inequality index which is significantly inferior than other major industralised countries and quite similar to those of many less developed countries (1). What is the evidence from micro studies of specific public expenditure programs such as health, public housing or education? It is only through such micro studies that we can determine what went wrong or what is the problem with the existing supply and pricing of public goods in Canada. My own study of the Ontario university system (7) is addressed to this issue. It treats the university system as a specific form of delivering a public good, and attempts to evaluate the impact of this delivery. The central concern is the following question: Why should higher education be subsidized by the general taxpayer unless its rewards or benefits are progressively provided enhancing the general well-being?

There are two central assumptions in the study: Firstly, that universities are wealthcreators, over and above other functions they perform, such as being repositories of knowledge or research centres. Secondly, the process of wealth creation in universities reflects a set of deliberate investment decisions jointly made by parents and students. These assumptions permit the application of the human capital model** for an assessment of the Ontario university system.

Since these are the basic assumptions of the study, it is desirable to explain them more fully. The wealth-creating effect of the university stems from the fact that the graduate acquires certain skills or specialized knowledge that commands a market value. This market value represents additional income which flows during the graduate's working life in the form of an income stream, much as the yield accruing to a bond-holder or revenue earned by an investor in some physical capital asset. Likewise, the costs of acquiring a university

*For a recent review see $(10)$.

**A summary statement of this theory is in (7, Chap. 1). 
education (made up of direct outlays and foregone earnings) can be treated as investment expenditures incurred in expected additional life-time earnings.

At this point, a word of explanation is in order to justify our application of the human capital theory. The reason why we are applying the human capital theory to the task at hand is that it lends itself to empirical analysis - not to demonstrate the validity of this theory as such. Applying it, as we do, does not necessarily imply that we accept as valid the "service station" role of universities solely meeting the scientific and technical manpower requirements of the economy. Neither do we necessarily accept or reject the "screening" hypothesis or the "credentialist" view of universitiest. Whether the universities do indeed create human capital embodied in the graduates, or whether they simply screen and filter students for employers, they influence the wealth distribution in the society, and this creates a social issue since higher education is an important example of public good.

The second basic assumption in my study is that university education represents a shared or joint investment by students and parents, implying that decisions to go or not to go to university are made at home as a result of consultations between parents and children, taking into account the family's financial situation, their expectations as well as the children's educational talents and qualifications. The assumption of joint investment in higher education is by no means an original idea. Indeed, the great British economist Alfred Marshall who wrote in 1890 that "the most valuable of all capital is that invested in human beings" explicitly recognized the role of parents in the educational and career choices of their children (6, p. 564 and pp. 456-7). Yet, there are some important issues raised by the joint investment assumption which must be recognized. One is the problem of divergence of costs and benefits of educational investments between the parents and students. It is the former who, either directly or indirectly through taxes, bear the major cost of higher education, whereas the beneficiaries are the children themselves. However, I would argue that the parents' investment decisions reflect far more than pure altruism; they, in fact, represent investment in upward social mobility, or put in economic terms, in altering the pattern of income distribution. A poor father who exhorts his son to go to university, and helps finance his education, so he can become 'somebody,' is a person actively trying to effect a change in the existing pattern of income distribution through the university system. It is this fact which, analytically speaking, justifies the basic assumption of joint investment decision; it is the same fact which permits the evaluation of the university system by income groups rather than by the standard procedure of private investors' behaviour.

There are, implicit in the above test, certain hidden views of equity which need to be explicitly stated. In fact, there are two concepts of equity: ex-ante and ex-post (8). The former refers to equal opportunity or access to university, and it merely attempts to provide, in some administrative or legal sense, equalized chance to all who may wish to go to university. I would like to suggest that this has been the traditional concept of equity which has dominated educational philosophy and recent policy on higher education in Ontario. It must, however, be distinguished from the ex-post concept of equity in the university system, which refers to the equity of results, namely the economic rewards 
derived from the wealth-creating effects of university education. Thus, if poorer families or students did not actually take advantage of their theoretical equal access chances (due to financial barriers or social/cultural reasons), and as a result participation in universities were heavily skewed in favour of the rich groups, the result of the existing university education would, undoubtedly, be inequitable in the ex-post sense, though quite equitable in terms of the ex-ante concept. In our study, we are particularly interested in the ex-post equity effects of the Ontario university system.

The third methodological issue concerns the appropriateness of evaluating higher education in isolation, for, after all, higher education is just one of a rather large bundle of 'public goods.' Thus, it can be argued that a regressive university system need not be socially unacceptable if there are other specific programs in the bundle of 'public goods' which are clearly progressive, and, therefore, potentially offsetting the regressivity of the university system, e.g. income transfers and welfare programs. This is clearly an elitist argument attempting to justify university as an elitist institution; it is entirely inconsistent with the rationale of a 'public good.' For example, why should the taxes of the lower income groups subsidize medical, law and dentistry schools in particular, and university education in general, when an inordinate proportion of the subsidies are used to provide a service below full cost to a student body drawn largely from wealthy families able to pay the full cost themselves? Furthermore, maintaining the poor through income transfers and welfare programs keep the poor functionally poor, whereas higher education is the passport for upward mobility and wealth acquisition - a most effective way to break out of poverty. Welfare programs are hardly comparable to university education in terms of their distributive justice implications.

\section{Calculating the Benefits: Graduates and their Earnings}

At the present time, there is no regular, inter-censal data source in Canada showing the socio-economic background of university students; neither is regular data available regarding post-graduation employment, earnings and labour market experience of the students. These data limitations make an objective evaluation of the equity effects of university education difficult and imperfect. In fact, such studies are only feasible on the basis of occasionally available data, derived from special surveys. This is true for the present study and it is readily admitted that our findings are far from being perfect and precise.

The key source of data on the socio-economic background of university students in our study is the Statistics Canada's Post-Secondary Student Survey (PSSS) 1974-75, which enabled us to construct a matrix cross-tabulating field of study by father's reported income. (This was the most reliable income data.) Both the income intervals and the definitions of fields of study were borrowed from the PSSS sources which of course, differed from definitions and categories used in other data sources which we were obliged to use, thus requiring tedious and imprecise conversion procedures*.

The other data sources used were the following. Statistics Canada's Consumer Finances Survey of 1974 was utilized to construct the education/earnings profiles for the university

*A fuller discussion of these matters is in (7) 
and high school graduates. Starting salaries of university graduates were obtained from a special survey of some 16,000 graduates in 1974 conducted jointly by the Ontario Ministry of Colleges and Universities and Statistics Canada. After considering various tests, it was found that the best fitting equation for the earnings profiles was the seconddegree polynominal, which was subsequently applied to the graduation matrix to compute additional lifetime earnings of the Ontario university graduates.

Our study is cross-sectional and it is limited only to male graduates of the class of 1974 full-time undergraduates. The exclusion of female students from our study was partly dictated by lack of reliable data about their labour market experience following graduation and partly owing to the difficulties of imputing economic value on home-making activities. The class-of-1974 male graduates were assumed to have entered university 4 years previously. Thus, the investment decisions were made jointly by the students and parents in 1970; accordingly, this date was selected for the calculation of the present values by means of discounting methods. All benefits and costs were converted to 1970 values.

It may be useful to highlight some initial observations from our data regarding graduation shares by income groups. We found confirmation for the general view that the children of the higher income-groups tend to concentrate in such high-paying fields as medicine, law, and dentistry. According to detailed PSSS data, the graduation shares of high-income groups (i.e. over $\$ 20,000$ ) were as follows: $54.3 \%$ in law, $26.3 \%$ in medicine and $20.1 \%$ in dentistry, compared with $2.8 \%, 9.1 \%$ and $3.4 \%$ respectively for the low income group (i.e. under $\$ 6,000$ ). In fact, we found that a significant proportion of enrolments in medical, law and dentistry schools consisted of children originating from high income families in which the father himself was a physician, lawyer or dentist. This indicates a significant volume of inter-generational human capital formation through the university system of Ontario, or what Porter has described as 'structured' inequality in the Canadian educated elite (9, Chap. 5).

In engineering and applied sciences, the mathematics and physical sciences, as well as agricultural and biological sciences, the graduation shares of lower income groups (under $\$ 6,000$ ) were higher, reflecting a less skewed enrolment pattern relative to the professional schools. In social sciences, humanities, fine arts and education, the graduation shares of the low income groups are relatively small, possibly reflecting high personal and non-cash benefits gained from such fields of study. (These can be presumed to be high for the wellto-do groups). As can be expected these fields were particularly dominated by children with middle income family backgrounds. (Table 1).

\section{The Cost Data: Investing in the Class-of-1974}

In our study, we were interested in determining the costs incurred in producing the classof-1974 male graduates. Conceptually this meant computing the expenditures of parents, as taxpayers, and direct expenses of students during their years of study. Of course, these expenditures had to be classified according to the income level of the graduates' parents, matching the income groupings employed in the calculation of benefits. The most difficult part of our cost calculations was the estimation of the tax burdens by income groups of parents. The difficulty was due to the fact that public grants for universities (accounting for about $80 \%$ of total expenditures) are not financed from a specific tax (such as a 
TABLE 1

GRADUATION SHARES OF THE CLASS-OF-1974 BY INCOME GROUPS

(in Percent)

\begin{tabular}{|l|c|c|}
\hline & \multicolumn{2}{|c|}{ Father's Income } \\
\hline \multicolumn{1}{|c|}{ Fields of Study } & $\begin{array}{c}\text { Less than } \\
\$ 6,000\end{array}$ & $\begin{array}{c}\text { Over } \\
\$ 20,000\end{array}$ \\
\hline Aciric. 'biological Science' & 26.6 & 22.6 \\
Eng. \& Applied Sciences & 19.6 & 23.8 \\
Maths. \& Physics & 20.4 & 8.6 \\
Social Scjences & 7.7 & 31.1 \\
Humanities & 2.1 & 28.3 \\
Fine Arts & 0.0 & 20.8 \\
Education & 7.4 & 20.2 \\
Law & 2.8 & 54.3 \\
Medicine & 9.1 & 26.3 \\
Dentistry & 3.4 & 20.1 \\
Health Professions Combined & 6.1 & 33.0 \\
\hline
\end{tabular}

SOURCE: 0 . Mehmet, Who Benefits from the ontario University System, Table 1, pp. 17-19.

'University Tax') but rather from general tax revenues raised from taxes on individual incomes, on corporations as well as municipal taxation and a wide-range of indirect taxes. As a result, estimating tax shares by income groups of parents of university graduates required tedious and extensive computations of tax shift based on rather arbitrary assumptions about specific tax incidence for specific income groups. Such a task was clearly beyond the scope of this study, and, therefore, we were obliged to use the results of a study by David Dodge on tax shifts (4). Fortunately, the Dodge analysis, too, was based on the year 1970, which coincided perfectly with the date of the investment decisions of the students and parents in our study.

But the use of the Dodge tax data introduced some biases into our results. First of all, his income intervals stopped at the upper limit of $\$ 15,000$ - well below those used in the PSSS data from which our benefit figures were computed. Accordingly, we were obliged to redefine upper income groups as those with incomes in excess of $\$ 15,000$. However, since these amounts were in 1970 values this particular bias may not be too severe. A more serious limitation stemmed from the fact that the Dodge income intervals were 
based on family incomes, whereas the PSSS intervals were derived only from father's income. This discrepancy can be expected to bias our findings by understating regressivity for the lower income groups since benefits for these groups would be smaller than our estimate if family income (rather than fathers' only) groupings had been used. I would submit, however, that understating regressivity for lower income groups is a more tolerable bias than overstating it, especially in view of our results.

The tax burdens of specific income groups in subsidizing the class-of-1974 male graduates were calculated by applying Dodge's over-all tax shares in conjunction with a proportionately assumption. That is to say, the total public funds invested in the class-of1974 male graduates was allocated amongst specific income groups in proportion to their over-all tax shares as estimated by Dodge. While the burden of public costs of universities may not correspond exactly to the over-all tax burden of socio-economic groups, the proportionately assumption is the most reasonable option in the absence of better data* The total public cost of the class-of-1974 male graduates included the operating grants over the 4-year academic program, administrative and overhead expenses, student aid as well as capital expenditures. Only the cost share of male full-time undergraduate student population, during 1970-74 was measured, this being done according to the enrolment share in each year of the full-time male undergraduates in the total university population.

Turning to the private costs, the following estimating procedures were used. Foregone earnings during the 4-year university program were taken into account in the calculation of the additional lifetime earnings of university graduates relative to those of high school graduates. That is to say, the lifetime earnings of the high school graduates were cumulated from age 18 to 65 whereas for university graduates they were cumulated from age 22 to 65. The cost of fees, for each income group, was computed in accordance with their respective enrolment shares over the period 1970-74.

Using an $8 \%$ discount rate in converting to 1970 values, total costs invested in the class-of-1974 male graduates were estimated at $\$ 1.189$ billion, of which $12 \%$ was contributed by the low-income groups compared with their overall graduation share of $8.9 \%$. On the other hand, the top income groups (those with more than $\$ 15,000$ ) paid $35 \%$ of the total cost and accounted for about $37 \%$ of the graduations. What might be considered the middle income groups (i.e. those in the $\$ 10,000-\$ 15,000$ range) carried about $25 \%$ of the cost burden for the class-of-1974 male graduates, while having a $34 \%$ share of total graduations. (Table 11).

\section{The Results: Benefit-Cost Ratios by Income Groups}

Although our results are not intended as precise or absolutely accurate indexes, there can be little doubt about the principal result: that the existing pattern of university education is regressive, or pro-rich. Indeed, the system can be described as a large publicly-financed service through which those in the lower income groups subsidize those in the higher income parents (i.e. $\$ 2,000-\$ 6,000$ ) received only $65 \notin-75 \notin$ return from the class-of-1974 male graduates, whereas parents in the middle and top income groups enjoyed returns significantly greater than a dollar. By far the largest gainers were parents in the

\footnotetext{
*This is a standard procedure used in similar studies. See (5)
} 
TABLE 11

TOTAL COSTS INVESTED IN CLASS-OF-1974 MALE GRADUATES

BY INCOME GROUPS

\begin{tabular}{|l|c|c|}
\hline Income Group & $\begin{array}{c}\text { Discounted at } 88 \\
(\$ \text { mill. })\end{array}$ & $\%$ \\
\hline Under $\$ 2,000$ & 16.5 & 1.4 \\
$\$ 2,000-\$ 4,000$ & 51.0 & 4.3 \\
$\$ 4,000-\$ 6,000$ & 74.6 & 6.3 \\
$\$ 6,000-\$ 10,000$ & 289.4 & 24.3 \\
$\$ 10,000-\$ 15,000$ & 340.9 & 28.7 \\
Over $\$ 15,000$ & 416.0 & 35.0 \\
\hline TOTAL & $1,189.0$ & 100.0 \\
\hline
\end{tabular}

SOURCE: O. Mehmet, op. cit., Table 7 .

$\$ 10,000-\$ 15,000$ bracket, who recouped $\$ 1.19$ per every dollar they invested. Parents in the top income group of over $\$ 15,000$ had a ratio of $\$ 1.05$ per dollar of expenditure (Table 111).

In fact, there are reasons to believe that these empirical results are minimal estimates of true regressivity in the Ontario University System. This is because our findings are based on the assumption that the rich and poor families have equal access to capital markets, that there is no discrimination in the labour market favouring the rich, and that the rich and poor families have uniform rates of time-preference. If one were to use alternative assumptions, then one would need to apply higher discount rates for the poorer families than for the rich, thereby obtaining even larger measures of regressivity greater than the ones reported in this study.

\section{Some Conclusions and Implications}

Because of the data limitations in our study, we have refrained from making any policy recommendations. Nevertheless, our study suggests that the existing student aid programmes, both federal and provincial, are structurally deficient in as much as they provide assistance only to students who manage to find their way to university; as such they fail to have any impact on potential entrants from lower-income backgrounds. In fact, a 
TABLE 111

BENEFIT-COST RATIOS FOR UNIVERSITY EDUCATION BY INCOME GROUPS, ONTARIO, 1974

\begin{tabular}{|c|c|c|c|c|c|}
\hline \multirow[t]{2}{*}{$\begin{array}{l}\text { Parents' } \\
\text { Income Groups }\end{array}$} & $\begin{array}{l}\text { Monetary } \\
\text { Benefits } \\
\text { (1) }\end{array}$ & $\begin{array}{l}\text { Net Budgetary } \\
\text { Cost } \\
(2) \\
\end{array}$ & \multirow[t]{2}{*}{$\begin{array}{l}\text { Benefit } \\
\text { Actual } \\
\text { (3) }\end{array}$} & \multirow[t]{2}{*}{$\begin{array}{l}\text { Cost Ratios } \\
\text { Standardized } \\
\text { (4) }\end{array}$} & \multirow{2}{*}{$\begin{array}{l}\text { Percentage of } \\
\text { students in income } \\
\text { class } \\
\text { (5) }\end{array}$} \\
\hline & \multicolumn{2}{|c|}{ (\$million) } & & & \\
\hline Under $\$ 2,000$ & 20.6 & 16.5 & 1.25 & 1.18 & 1.6 \\
\hline$\$ 2,000-\$ 4,000$ & 39.6 & 51.0 & .78 & .74 & 3.0 \\
\hline$\$ 4,000-\$ 6,000$ & 51.3 & 74.6 & .69 & .65 & 4.1 \\
\hline$\$ 6,000-\$ 10,000$ & 254.3 & 289.4 & .88 & .83 & 20.2 \\
\hline$\$ 10,000-\$ 15,000$ & 430.9 & 340.9 & 1.26 & 1.19 & 34.1 \\
\hline$\$ 15,000$ and over & 462.6 & 416.0 & 1.11 & 1.05 & 37.0 \\
\hline ALL GROUPS & .259 .0 & $1,188.4$ & 1.06 & 1.00 & 100.00 \\
\hline
\end{tabular}

Notes: The calculations assume an 88 discount rate and are based on the economic costs and benefits of producing the class-of-1974 male graduates in 1970 values.

SOURCE: 0 . Mehmet, op. cit., Tables 1 and 7 . 
regression analysis of these programmes which we conducted showed that, while the programmes are progressively administered, the principal beneficiaries are the higher income groups who account for a high share of actual enrolments and who, therefore, end up receiving the largest share of the assistance funds. Clearly, the student aid programmes are not designed to bring about a new (i.e. more egalitarian) profile of enrolments; that is, they do not operate as instruments of promoting greater accessibility or educational opportunity from the disadvantageous socio-economic groups.

It is for this reason that we have made a strong plea for some sort of an Advanced Voucher System (AVS), awarding scholarships to promising students from poor families while they are in grade 9 in the high school. For the decisions to go to university are made, jointly by parents and students, at this juncture in the high school when academic streaming occurs. I believe there is strong evidence justifying the AVS: According to a 1969 study of urban students and their socio-economic backgrounds, only $26 \%$ of grade 9 students from families with less than $\$ 5,000$ reached grade 13 , compared with $58 \%$ for families with over $\$ 10,000$ implying a strong negative correlation between dropping out of high school and family income (3). The same study, and similar other studies, have indicated a strong acceptance among poor families of the value of higher education; nevertheless, their desire to acquire university education always outstrips their actual expectations, i.e. there is a case of unfulfilled expectations among the lower income groups vis-a-vis university education. In more economic terms, there is potential (unmet) demand for university places among the poor groups refuting the elitist views to the contrary. Consequently, if an AVS were instituted, some of this potential could be salvaged and the participation rate of the lower income groups in universities raised, although, of course, cultural and sociological factors (as distinct from purely financial ones) may still present obstacles to entry.

In conclusion our study throws some useful light on the reasons for the failure of the "Great or Just Society" programmes of the recent past to promote greater economic equity through the instrumentality of public goods and services, such as university education. It suggests that the trend of increased income inequality since 1965, noted at the outset, may be due to the fact that, while the tax burden of providing these public goods is borne generally by the taxpayers, the economic rewards created in the process are recouped primarily by the more privileged and well-to-do groups.

The expansionary higher educational policies of the 1960's, however successful in promoting ex-ante equality of opportunity, have nevertheless failed to promote ex-post equity, i.e. to distribute the economic rewards of higher education more equitably, as originally rationalized by the theory of public goods. In specific terms, the sorts of university education policies adopted in the last decade were unable or inappropriate to increase the enrolment share in universities of students from low income backgrounds. This, of course, is the basic explanation for the regressive results reported in this study.

To end on a rather dogmatic note, there are two main policy options for future university educational policy: (1) Remove higher education from the list of public goods and services paid for by the general taxpayer, and instead rely on a full, user-cost financing formula, even though doing this would convert universities into private, elitist institutions; or (2) maintain the public subsidy of universities, but reform its financing and supply expressly to bring about a more equal wealth distribution in accordance with the notion 
51 The Ontario University System as Wealth-Creator

of ex-post equity. Of course, the latter is the more feasible option, although, as with egalitarian reforms in general, it may not command full political support.

\section{REFERENCES}

1. M.S. Ahluwalia. "Inequality, Poverty and Development" Journal of Development Economics, Vol. 3, 1976.

2. M. Blaug. "The Human Capital Theory: A Slightly Jaundiced Survey" Journal of Economic Literature, Vol. 14, No. 3, September 1976.

3. Edmund Clark, David Cook, George Fallis. "Socialization, Family Background and the Secondary School" in Robert Pike and Elia Zuriek, eds., Socialization and Values in Canadian Society, Vol. 2, McClelland and Stewart, Toronto, 1975.

4. David Dodge. "Impact of Tax Transfer and Expenditure Policies of Government on the Distribution of Personal Income in Canada" Review of Income and Wealth, Series 21, No. 1, March 1975.

5. W. Lee Hansen and Burton A. Weisbrod. Benefits Cost and Finance of Higher Education, Markham, Chicago, 1970.

6. A. Marshall. Principles of Economics, MacMillan, London 1962.

7. Ozay Mehmet, Who Benefits from the Ontario University System, A Benefit-Cost Analysis by Income Groups. Ontario Economic Council, Toronto. Occasional Paper No. 7, 1978.

8. Mark Pauly and Thomas Willett, "Two Concepts of Equity and Their Implications for Public Policy" Social Science Quarterly, Vol. 53, No. 1, June 1972.

9. John Porter, The Vertical Mosaic, Toronto, University of Toronto Press, 1967.

10. Grant L. Reuber. "The Impact of Government Policies on the Distribution of Income in Canada: A Review". Canadian Public Policy. (forthcoming).

11. Statistics Canada. Income Distributions by Size in Canada 1974, Cat. No. 13-207, Annual. 1976. 